\title{
Predicting Financial Distress in Companies Using the Original CCB Model
}

\section{Vitezslav HALEK}

University of Hradec Kralove, Czech Republic; vitezslav.halek@uhk.cz

\begin{abstract}
The aim of this research was to present a new methodology for the assessment of financial health of a company, called the Come Clean Bankruptcy (CCB) model. The ultimate objective of the model is to detect the signs of impending bankruptcy based on a set of selected financial indicators reflecting the capital structure, liquidity and overall growth of the company. The CCB model was applied on a data sample comprising 199 entities operating in the textile/clothing industry in the Czech Republic. The outputs were compared with the actual development of those companies in 2013-2020 in order to assess whether the model can be effectively employed in practice. especially in court proceedings, specialization criminal law. Courts are often faced with the question of determining the date on which a bankruptcy situation arose. The CCB model evaluates past data. Therefore, it is a suitable tool for proving whether the management knew about the economic development of the company.
\end{abstract}

Keywords: bankruptcy model; predicting risks; financial distress; Czech Republic

JEL Classification: C51; C52; C53

\section{Introduction}

Nowadays, there is a wide range of available organizational and financial measures for saving companies that found themselves in financial distress, each corresponding to the specific circumstances in the company and the causes of the financial distress. Though the efficacy of those measures is ever increasing, there is little doubt that it is much more advantageous, both in terms of time and financial costs, to prevent the bankruptcy in the first place, rather than to solve it once it occurs.

Bankruptcy is often misinterpreted. It is not the cause of the decline in value. It is the consequence of the decline. Above all, it represents a legal remedy allowing the creditors to take over a business that fails to meet its obligations due to the said decline in the value of assets. This means that with suitable tools, it is indeed possible to detect certain symptoms leading to the onset of bankruptcy. Financial analysis and corresponding models represent such tools.

The quality of existing financial analysis systems is determined directly by their complexity. Despite the fact that elementary methods of processing the data do not have the necessary explanatory power, they are used quite often. Complex systems allow for a more detailed depiction of the situation in the company, yet they tend to be confusing for the users of financial analyses. In fact, it has been shown that the users of financial analysis are able to understand less than three quarters of the analysis (Forrer, 1991). One of the main objectives 
of the proposed model, unlike many other creditworthy/bankruptcy models, therefore is to provide a clear explanation of the obtained results.

Virtually all financial analyses require the use of data reported in financial statements. However, accounting data alone only reflects the past and not the prospects for the future. In other words, it defines the current values of strongly variable quantities (Kovanicova, 1999). These shortcomings can be eliminated by comparing the data with each other, expanding its explanatory power. That is why financial ratios are the fundamental methodological tool for financial analysis. Prediction models are often based on recommended values of indicators, which are nevertheless too broad. The CCB model, on the other hand, compares the individual ratios of a selected company with values of 199 competing entities operating in the same sector of economy, which increases the explanatory power of data and accuracy of the analysis. In addition, as a benchmark, it uses real data of entities which went bankrupt in the past in order to recognize patterns of impending bankruptcy.

\subsection{Indicators of Financial Distress}

One of the ways to recognize the patterns of impending bankruptcy is to follow the indicators of sustainable development of a company. The definition of sustainable development was first discussed by professor Robert C. Higgins (1984). It represents a situation of the company in which:

- Assumption A Proportional increase in sales = proportional increase in capital.

- Assumption B Equity is increased by retained earnings only.

- Assumption C The debt ratio does not change.

These assumptions are nevertheless not always valid. For example, equity does not always have to increase exclusively by the amount of retained earnings and increase in sales does not necessarily leads to increase in the value of total capital.

The main components defining sustainable development are as follows:
a) Return on sales
b) Dividend pay-out ratio
c) Debt ratio
d) Capital turnover rate

The proposed CCB model does not claim that respecting the main components of the sustainable development indicators leads to the growth / prosperity of a company, as proclaimed by many creditworthy models. It suggests that failure to respect the selected components leads to financial problems for the company.

The optimal capital structure is a major element affecting the likelihood of bankruptcy. The key work on the optimal capital structure of companies was written by economists Miller and Modigliani (1958). They concluded that, under certain conditions, the value of a company is independent of the company's capital structure. By gradually removing the assumptions of Miller and Modigliani's model, their followers (Jensen \& Meckling, 1976; Myer \& Majluf, 1984) and they themselves proved that the optimal capital structure exists and that it can be 
approximately determined with mathematical calculations (Hluzkova, 2001). With moderate levels of indebtedness, the probability of distress is negligible and the tax benefits predominate. However, at some point, as the company continues to borrow more funds, the likelihood of financial distress dramatically increases. The company reaches a theoretical optimum when the current value of tax savings from additional borrowings is offset by an increase in the current costs of distress. Bankruptcy costs are born by creditors. Creditors, aware of this fact, demand compensation (in advance) in form of higher payouts, when the company is meeting its obligations. Standard financial analysis models (bankruptcy models) often consider the debt-to-equity ratio as a compromise between interest tax shield and costs of financial distress. In the domain of financial analysis, there are disputes about the influence of the interest tax shield on financial difficulties in general.

Another factor worth considering, in regards to the likelihood of bankruptcy, is the company's liquidity. The liquidity represents the probability of when and under which conditions the difference between company's income / expenditures will be balanced. The signs of imminent financial distress / bankruptcy of a company apparent from the evolution of cash flows (Table 1) over five years include:

Table 1. Signs of imminent financial distress

\begin{tabular}{|l|l|}
\hline \multicolumn{1}{|c|}{ Decrease in } & \multicolumn{1}{c|}{ Increase in } \\
\hline Cash flow caused by decrease in profit & Short-term bank loans \\
\hline Income, slower decrease in expenditures & Interests \\
\hline $\begin{array}{l}\text { Net cash flow caused by an increase in inventories } \\
\text { and short-term receivables }\end{array}$ & Capital expenditures \\
\hline Long-term debts & \\
\hline Working capital & \\
\hline
\end{tabular}

\section{Methodology}

The CCB model methodology can be divided into 6 main stages, each corresponding to a specific way of processing the input data (Table 2).

Table 2. CCB model methodology

\begin{tabular}{|c|c|c|c|}
\hline \multicolumn{2}{|r|}{ Stage } & Reason & Goal \\
\hline 1 & Ratios & $\begin{array}{l}\text { Comparing companies according to } \\
\text { absolute values is misleading }\end{array}$ & $\begin{array}{l}\text { Organizing input data in order } \\
\text { to set up the Du Pont chart }\end{array}$ \\
\hline 2 & Du Pont chart & $\begin{array}{l}\text { Global incorporation of examined } \\
\text { variables }\end{array}$ & Defining financial leverage \\
\hline \multirow{2}{*}{3} & \multirow{2}{*}{$\begin{array}{l}\text { Monitoring of the break- } \\
\text { even point and financial } \\
\text { leverage }\end{array}$} & $\begin{array}{l}\text { The value of the company is affected } \\
\text { by financial leverage }\end{array}$ & $\begin{array}{l}\text { Defining the optimal } \\
\text { indebtedness }\end{array}$ \\
\hline & & $\begin{array}{l}\text { Considering company's } \\
\text { performance }\end{array}$ & Company's risks \\
\hline 4 & $\begin{array}{l}\text { Incorporation of competing } \\
\text { entities }\end{array}$ & Intercompany comparison & $\begin{array}{l}\text { External environment of the } \\
\text { company }\end{array}$ \\
\hline 5 & Global analysis & Analysis of non-economic variables & Company as a whole \\
\hline 6 & $\begin{array}{l}\text { Bankruptcy intervals and } \\
\text { decisions }\end{array}$ & $\begin{array}{l}\text { Determining the probability of } \\
\text { bankruptcy over time }\end{array}$ & Deciding on bankruptcy \\
\hline
\end{tabular}


The model is based on the following 11 financial ratios that are necessary for the prediction of financial distress. Abbreviations used in the equations are explained in Appendix.

$$
\frac{L D+L V}{L D+C V+\text { capital }}
$$

When a company borrows funds, it is expected to pay regular instalments. Debt provides the basis for financial leverage, since shareholders obtain the remaining amount once the creditors are paid off. Financial leverage has various definitions. For the purpose of the CCB model, the value of liabilities is added to the ratio of long-term debt to total capital, because long-term liability agreements (lease) oblige the company to pay a series of fixed payments.

Debt ratio is followed by earnings-to-interest ratio:

$$
\frac{E B I T+A}{\text { Interest }}
$$

Regular interest payments represent an obstacle that companies have to deal with in time to avoid bankruptcy. This ratio provides information on when the interest payments will no longer be covered by earnings.

$$
\frac{A_{C}-D_{\text {outstanding }}+A P+L i_{\text {other }}}{A_{\text {total }}}
$$

The creditor / analyst must assess whether the company will have enough cash to repay its debt, even in short-term horizon. The focus should therefore be on liquid assets. The weight of the liquidity ratio is insignificant in the model, as liquidity ratios are highly volatile. The ratio of net working capital to total assets is considered as the gross ratio of potential cash.

$$
\frac{\text { Cash }+M S}{L_{C}}
$$

The liquidity of assets also plays an important role. It is best illustrated on cash, marketable securities and outstanding receivables. The numerator of the ratio can be net of receivables, which seems like a more suitable option for bankruptcy purposes.

$$
\frac{\text { Cash }+M S+\text { Receivables }}{D O E}
$$

The equation 4 was modified by adding receivables and daily operating expenditure in order to yield another financial ratio analysed by the mode.

$$
\frac{E B I T-(\operatorname{tax}+T S)}{A_{a}}
$$

Company performance is assessed with the return on total assets. If only operating performance is to be measured, we need to add interest tax shields to the taxes. This will allow to obtain taxes that the company would pay had it been fully funded by shares. Return is defined as earnings before interest, but after tax (with the $20 \%$ tax rate) and tax shields are obtained by multiplication of the tax rate and net interest. Rising assets in the denominator 
put pressure on lower returns. This structure enables a comparison of entities with significantly different debt ratios.

$$
\frac{P_{s}}{E_{S}}
$$

The price-to-earnings ratio is a common evaluation benchmark used by investors. A high $\mathrm{P} / \mathrm{E}$ ratio means that:

1. the investors expect significant dividend growth or,

2. the stock is not particularly risky, meaning that investors are prepared for smaller returns, or

3. the company anticipates a significant average growth and therefore pays out a large share of its earnings.

$$
\frac{P_{S}}{R C^{c}}
$$

The last fundamental characteristic observed within the CCB model is the relationship between the share price and its book value, which can be obtained with Tobin's $Q$. This ratio is similar to the market / book value ratio, except that the numerator q includes all debt + equity of the company, not just net equity. Similarly, the denominator includes all assets and not just net capital. These assets are reported in replacement costs, not acquisition costs.

The final three indicators - Interest tax shield (9), Expected Return on Debt (10) and Indebtedness (11) are presented below:

$$
\frac{(\text { EBITDA }+(\text { EBIT }- \text { EAT })+(\text { interest expenses } * 0,2))}{\sum \text { LIABILITIES }}
$$

$$
\begin{gathered}
\frac{\text { Operating Profit }}{\text { Equity }} \\
\frac{E A T}{\sum \text { LIABILITIES }}+\text { Debt Ratio } * \frac{\text { EAT }}{\sum \text { LIABILITIES - Expected Return on Debt }}
\end{gathered}
$$

The Du Pont analysis helps to get a better understanding of some of the key metrics of company's health, such as profit margin, financial leverage (calculated as total assets to total equity) or optimal equity-to-debt ratio. The standard DuPont diagram also contains information concerning the revenues and expenditures of analysed companies. The breakeven point shows how operating income / cash flow is affected at different levels of expenditures and sales. We can assess whether a company uses its debt properly by comparing the return on equity to return on loans. The degree of operating leverage is defined as the change (\%) in earnings per share to EBIT. Financial leverage provides interesting information. Comparison of the change in a) earnings per share and b) EBIT of the analysed company informs us about the risk that is taken by the shareholders. 
Intercompany comparison of financial ratios represents a key element of the newly proposed model. The prediction provided by the model is retrospective; it uses past data (from 2013) to predict the development in companies during the following 7-year time span (2013-2020). The use of current data was for obvious reasons impossible (we would have to wait in order to see whether the prediction was accurate or not).

The incorporation of competing entities starts with the calculation of arithmetic mean (12) and standard deviation (13):

$$
\begin{gathered}
\bar{x}=\frac{1}{N} \sum_{i=1}^{N} x_{i} \\
s=\sqrt{\frac{1}{N-1} \sum_{i=1}^{N}\left(x_{i}-\bar{x}\right)^{2}}
\end{gathered}
$$

The arithmetic mean (xpj) and standard deviation (sxj) are then used in the process of standardization of individual indicators:

$$
\begin{gathered}
u_{i j}=\frac{x_{i j}-x_{p j}}{s_{x j}} \\
u_{o j}=\frac{x_{o j}-x_{p j}}{s_{x j}}
\end{gathered}
$$

where the value of xij represents the value of the $j$-th indicator in the $i$-th company and uij and uoj are the values of standardized variables. The equation (14) is used when the indicator has a +1 value whereas the equation (15) is used for indicators with a -1 value. Standard deviation is an estimate of the scale / uncertainty of the data. This method therefore eliminates the main deficiency of other methods, which is the insensitivity to the variance of values. The results obtained with this method are less sensitive to the extreme values of indicators within the set of companies.

The companies are ranked based on the integral dsv indicator. It is calculated as the arithmetic mean of the standardized values of individual indicators for the i-th company:

$$
d s v=\frac{\sum_{j=1}^{m} u_{y} * p_{j}}{\sum_{j=1}^{m} p_{j}}, i=1,2, \ldots, n
$$

The last step in the incorporation of competing entities consists of assigning the companies to one of the three intervals, based on their ranking. The lower $9 \%$ of the companies are considered being at high risk of bankruptcy. Those that ranked in the bottom $9-22 \%$ are considered approaching bankruptcy. The remaining $78 \%$ represent the companies for which bankruptcy could not be predicted. 


\section{Results}

The first step of analysis consisted of collecting the data and calculating the financial ratios for each entity, as shown in Table 3. Table 4 includes arithmetic mean (xpj) along with standard deviation (Sxj) for each of the indicators, and the values of companies are transformed in the standardized form. The last step consisted of defining the integral indicator dsv in order to determine the final ranking of each entity. Entities were finally assigned to the corresponding risk interval based on the probability of bankruptcy.

Table 3. Indicators of Financial Distress

\begin{tabular}{|c|c|c|c|c|c|c|c|c|c|c|c|}
\hline 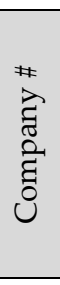 & 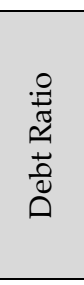 & 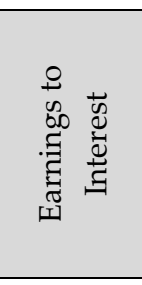 & 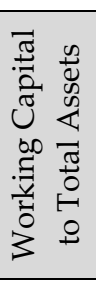 & 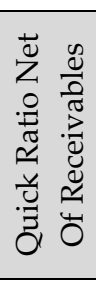 & 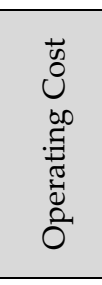 & 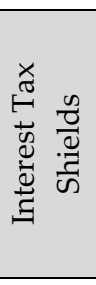 & 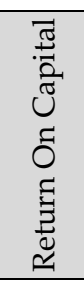 & 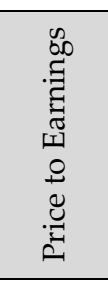 & 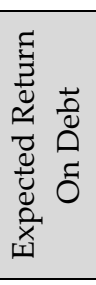 & $\begin{array}{l}\frac{0}{3} \\
\frac{\pi}{3} \\
0\end{array}$ & 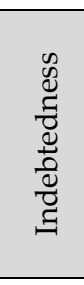 \\
\hline 1 & 0.63 & -7.26 & -0.76 & 0.01 & 3.89 & -0.00 & -0.06 & -7.78 & -0.20 & 0.70 & 0.03 \\
\hline 2 & 0.52 & -45.94 & -0.11 & 0.23 & 1.01 & -0.10 & -0.17 & 18.29 & -0.21 & 10.21 & -0.16 \\
\hline 3 & 0.06 & 9.92 & 0.44 & 1.67 & 5.43 & 0.06 & 0.01 & 88.73 & 0.02 & 0.61 & 0.01 \\
\hline 4 & 1.94 & 0.00 & 0.26 & 0.03 & 2.42 & -0.43 & -0.43 & 1.87 & 0.87 & 2.28 & -2.90 \\
\hline 5 & 1.19 & 0.00 & -0.20 & 0.11 & 2.15 & 0.06 & 0.03 & 1.05 & 0.20 & 1.25 & -0.11 \\
\hline 6 & 1.02 & -4.76 & 0.22 & 0.07 & 0.72 & -0.09 & -0.11 & -0.62 & -4.15 & 1.90 & 3.87 \\
\hline 7 & 0.72 & 28.74 & -0.40 & 0.27 & 5.83 & 0.13 & 0.11 & -15.58 & 0.34 & 1.66 & -0.06 \\
\hline 8 & 0.41 & -81.99 & 0.46 & 1.58 & 6.92 & 0.18 & 0.04 & -1.93 & 0.40 & 2.14 & -0.23 \\
\hline 9 & 0.52 & 0.00 & 0.50 & 1.73 & 23.62 & 0.00 & 0.00 & 7.05 & 0.10 & 2.41 & -0.09 \\
\hline 10 & 0.23 & 23.16 & 0.54 & 0.84 & 2.01 & 0.12 & 0.07 & 12.63 & 0.10 & 2.21 & 0.07 \\
\hline 11 & 0.27 & $36,875.57$ & 0.38 & 0.54 & 1.30 & 0.61 & 0.11 & 7.98 & 0.17 & 1.56 & 0.09 \\
\hline 12 & 0.25 & 0.00 & 0.69 & 4.26 & 359.84 & 0.30 & 0.23 & -20.43 & 0.11 & 1.20 & 0.27 \\
\hline 13 & 0.06 & 0.00 & 0.88 & 16.96 & 3.82 & 0.20 & 0.13 & 8.35 & 0.17 & 3.42 & 0.13 \\
\hline 14 & 0.46 & -6.26 & 0.72 & 0.28 & 4.07 & -0.11 & -0.12 & 171.74 & -0.15 & 1.06 & -0.11 \\
\hline 15 & 0.59 & -4.86 & -0.12 & 0.01 & 2.46 & -0.06 & -0.12 & -1.59 & 4.59 & 0.72 & -4.93 \\
\hline 16 & 0.59 & 3.55 & 0.34 & 0.07 & 1.91 & 0.03 & 0.01 & 23.93 & 0.04 & 1.30 & -0.02 \\
\hline 17 & 0.48 & 2.11 & 0.53 & -0.20 & 0.49 & 0.06 & 0.04 & -3.76 & 0.17 & 2.31 & -0.03 \\
\hline 18 & 0.51 & 17.58 & 0.38 & 0.17 & 2.11 & 0.09 & 0.01 & 10.45 & 0.01 & 1.55 & 0.01 \\
\hline 19 & 0.62 & 12.49 & -0.03 & 0.05 & 2.21 & 0.11 & 0.05 & 3.11 & 0.15 & 1.19 & -0.02 \\
\hline 20 & 0.32 & -38.66 & 0.17 & 0.32 & 2.13 & -0.13 & -0.18 & 7.84 & -0.37 & 1.81 & -0.06 \\
\hline
\end{tabular}

As mentioned above, the CCB model used data reported for 2013 in order to predict evolution of selected companies during the following 7 years. According to the prediction, a total of 15 companies were at high risk of bankruptcy and 34 were approaching this state. Bankruptcy could not be predicted, but at the same time not ruled out, for the remaining 199 companies in the referential package.

A retrospective look at the real data shows that between 2013 and 2020, there were 9 companies ( $4.5 \%$ of the referential package) that either actually went bankrupt or have initiated insolvency proceedings. Out of the nine companies, three were successfully identified by the CCB model as "being at high risk of bankruptcy” or "approaching bankruptcy". These were the companies Durocas Czech s. r. o., PRVNÍ CHRÁNĚNÁ DÍLNA s.r.o. and Schwinn Tschechien s.r.o. 
Table 4. Ranking based on standardized values

\begin{tabular}{|c|c|c|c|c|c|c|c|c|c|c|c|c|c|c|}
\hline 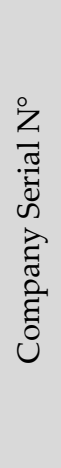 & 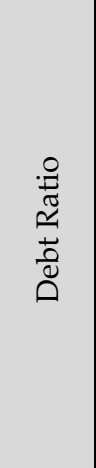 & 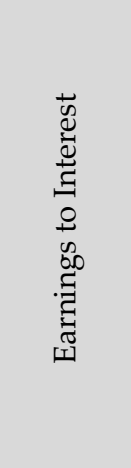 & 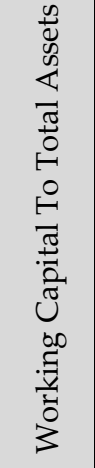 & 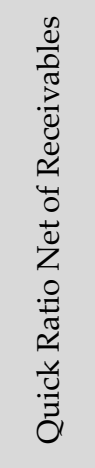 & 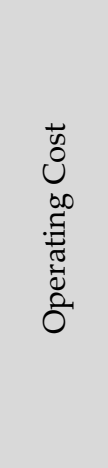 & 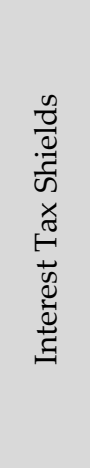 & 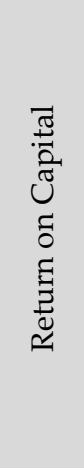 & 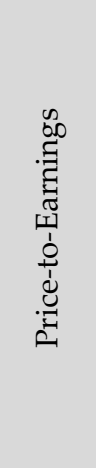 & 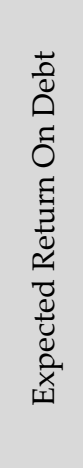 & 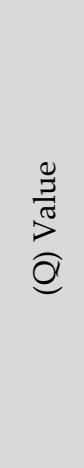 & 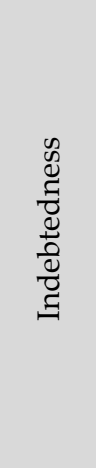 & 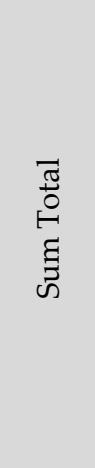 & 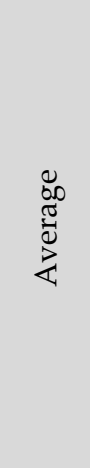 & $\begin{array}{l}\text { שี } \\
\text { జ }\end{array}$ \\
\hline$X_{p j}$ & 1.67 & 295.51 & -0.05 & 0.92 & 19.12 & 0.16 & 0.09 & 11.72 & 0.21 & 2.27 & 3.04 & $\times$ & $\times$ & $x$ \\
\hline$S_{x j}$ & 9.42 & $1,681.02$ & 3.14 & 6.15 & 224.43 & 1 & 1 & 44.98 & 1.05 & 3.85 & 46.99 & $x$ & $\times$ & $x$ \\
\hline 11 & -0.15 & 21.76 & 0.14 & -0.06 & -0.08 & 0.45 & 0.02 & -0.08 & -0.04 & -0.18 & -0.06 & 21.72 & 1.97 & 1 \\
\hline 12 & -0.15 & -0.15 & 0.24 & 0.54 & 1.52 & 0.15 & 0.14 & 4.1 & -0.1 & -0.28 & -0.06 & 5.95 & 0.54 & 2 \\
\hline 13 & -0.17 & -0.14 & 0.3 & 2.61 & -0.07 & 0.05 & 0.04 & -0.08 & -0.04 & 0.3 & -0.06 & 2.74 & 0.25 & 3 \\
\hline 14 & -0.13 & -0.15 & 0.25 & -0.1 & -0.07 & -0.21 & -0.21 & 3.56 & -0.12 & -0.31 & -0.01 & 2.5 & 0.23 & 4 \\
\hline 15 & -0.11 & -0.15 & -0.24 & -0.15 & -0.07 & -0.24 & -0.24 & -0.08 & 4.18 & -0.4 & -0.02 & 2.48 & 0.23 & 5 \\
\hline 2 & -0.12 & -0.15 & -0.1 & -0.11 & -0.08 & -0.17 & -0.17 & 0.15 & 0.23 & 2.06 & -0.01 & 1.53 & 0.14 & 6 \\
\hline 3 & -0.17 & -0.17 & 0.16 & 0.12 & -0.06 & -0.1 & -0.08 & 1.71 & -0.19 & -0.43 & -0.06 & 0.73 & 0.07 & 7 \\
\hline 6 & -0.07 & -0.15 & 0.09 & -0.14 & -0.08 & -0.09 & -0.13 & -0.11 & 1.16 & -0.1 & 0.02 & 0.4 & 0.04 & 8 \\
\hline 8 & -0.13 & -0.16 & 0.17 & 0.11 & -0.05 & 0.03 & -0.05 & -0.12 & 0.18 & -0.03 & -0.01 & -0.06 & -0.01 & 9 \\
\hline 4 & 0.03 & -0.15 & 0.1 & -0.14 & -0.07 & -0.21 & -0.21 & -0.22 & 0.63 & 0 & 0 & -0.24 & -0.02 & 10 \\
\hline 9 & -0.12 & -0.15 & 0.18 & 0.13 & 0.02 & -0.15 & -0.09 & -0.1 & -0.1 & 0.04 & -0.03 & -0.37 & -0.03 & 11 \\
\hline 10 & -0.15 & -0.16 & 0.19 & -0.01 & -0.08 & -0.04 & -0.02 & 0.02 & -0.1 & -0.02 & -0.06 & -0.43 & -0.04 & 12 \\
\hline 1 & -0.11 & 0 & 0 & -0.15 & -0.07 & 0 & 0 & 0 & 0 & -0.41 & -0.06 & -0.8 & -0.07 & 13 \\
\hline 16 & -0.11 & -0.17 & 0.13 & -0.14 & -0.08 & -0.12 & -0.09 & 0.27 & -0.16 & -0.25 & 0 & -0.72 & -0.07 & 14 \\
\hline 17 & -0.13 & -0.17 & 0.19 & -0.42 & -0.08 & -0.09 & -0.05 & -0.13 & -0.04 & 0.01 & 0 & -0.91 & -0.08 & 15 \\
\hline 18 & -0.12 & -0.17 & 0.14 & -0.12 & -0.08 & -0.06 & -0.08 & -0.03 & -0.19 & -0.19 & -0.06 & -0.96 & -0.09 & 16 \\
\hline 20 & -0.14 & -0.14 & 0.07 & -0.1 & -0.08 & -0.08 & -0.13 & -0.09 & -0.17 & -0.12 & 0 & -0.98 & -0.09 & 17 \\
\hline 19 & -0.11 & -0.17 & -0.09 & -0.14 & -0.08 & -0.04 & -0.05 & -0.19 & -0.06 & -0.28 & 0 & -1.21 & -0.11 & 18 \\
\hline 5 & -0.05 & -0.15 & -0.16 & -0.13 & -0.08 & -0.09 & -0.06 & -0.24 & -0.01 & -0.26 & -0.07 & -1.3 & -0.12 & 19 \\
\hline 7 & -0.1 & -0.16 & -0.95 & -0.11 & -0.06 & -0.03 & 0.01 & -0.38 & 0.12 & -0.16 & -0.07 & -1.89 & -0.17 & 20 \\
\hline
\end{tabular}

\section{Conclusions}

Despite the fact that financial distress or bankruptcy may have a slightly different definition depending on the legislation applicable in particular country or state, it is always perceived as a situation that should be avoided. Prevention of bankruptcy is indeed always more convenient and less expensive than resolving the bankruptcy that already occurred. Due to the current pandemic and resulting uncertainty in the markets, we can expect that the interception of potential risks of financial distress will move even higher in the list of management priorities.

The presented CCB model is an analysis instrument designed specifically for this very purpose. It aims to detect the signs of impending bankruptcy based on selected indicators of financial health of a company, including sustainable development, optimal capital structure and liquidity. Ensuring the applicability of the model in practice was one of the key objectives 
of the research. Its explanatory power was therefore tested on the data of 199 companies operating in the textile / clothing industry in the Czech Republic.

The comparison of predicted development and actual evolution of tested entities has shown that the CCB model was able to predict bankruptcy / insolvency proceedings in one third of the cases, despite the fact that the number of companies which found themselves in this situation was rather small, considering the extent of the referential package (only 9 out of 199). All the data required for the prediction were taken from standard financial statements.

It can thus be concluded that the described model represents a suitable and reliable tool for detecting financial distress in companies. Bankruptcy or insolvency is nevertheless a legal situation arising under specifically defined conditions. The CCB model should therefore be perceived as a mere support tool for the management and its outputs should prompt a further analysis or expert opinion of the circumstances in the given company.

\section{References}

Bauweraerts, J. (2016). Predicting Bankruptcy in Private Firms: Towards a Stepwise Regression Procedure. International Journal of Financial Research, 7(2), 147-153. https://doi.org/10.5430/ijfr.v7n2p147

Dutzi, A., \& Rausch, B. (2016). Earnings Management before Bankruptcy: A Review of the Literature. Journal of Accounting and Auditing: Research E Practice, 1-21. https://doi.org/10.5171/2016.245891

Forrer, J. (1991). Calculating Growth: Software Used for Financial Analysis in Economic Development. Social Science Computer Review, 9(2), 220-221. https://doi.org/10.1177/089443939100900225

Karas, M., \& Režňáková, M. (2015). Predicting Bankruptcy under Alternative Conditions: The Effect of a Change in Industry and Time Period on the Accuracy of the Model, 213, 397-403. https://doi.org/10.1016/j.sbspro.2015.11.557

Kovanicova, D., et al. (1999). Finanční účetnictví. Prague: Polygon.

Modigliani, F., \& Miller, K. H. (1958). The Cost of Capital, Corporation Finance and the Theory of Investment. American Economic Review, 48(3), 261-297.

Myer, S. C., \& Majluf, N. C. (1984). Corporate Financing and Investment Decisions When Firms Have Information that Investors do Not Have. Journal of Financial Economics, 13(2), 187-221. https://doi.org/10.1016/0304-405X(84)90023-0

Schwartz, A. (2016). Bankruptcy Related Contracting and Bankruptcy Functions. Oxford Business Law Blog, 9 , 363-394. https://doi.org/10.4337/9781781007884.00022

White, M. J. (2016). Small Business Bankruptcy. Annual Review of Financial Economics, 8(1), 317-336. https://doi.org/10.1146/annurev-financial-121415-032856 


\section{Appendix}

Table A1. Serial numbers of the companies. Companies in grey went bankrupt during the predicted period.

\begin{tabular}{|l|l|}
\hline Company \# & Company Name \\
\hline 1 & Actual spinning a.s \\
\hline 2 & ATRON, s.r.o \\
\hline 3 & BRULEKO s.r.o \\
\hline 4 & DIVERSO KV s.r.o. \\
\hline 5 & Durocas Czech s. r. o. \\
\hline 6 & KONYA - M s.r.o. \\
\hline 7 & PRVNÍ CHRÁNÉNÁLNA s.r.o \\
\hline 8 & RESCUE s.r.o \\
\hline 9 & SAND s.r.o \\
\hline 10 & CZ FORUS s.r.o \\
\hline 11 & BIKERS CROWN, s.r.o \\
\hline 12 & Clonestar Peptide Services, s.r.o \\
\hline 13 & Fibertex Nonwovens, a.s \\
\hline 14 & MEDOVINKA, s.r.o \\
\hline 15 & VEBA, textilní závody a.s. \\
\hline 16 & VLNAP a.s \\
\hline 17 & ASSANTE s.r.o \\
\hline 18 & B E M A T E C H, s.r.o \\
\hline 19 & GUMOTEX, a.s. \\
\hline 20 & Schwinn Tschechien s.r.o \\
\hline &
\end{tabular}

Table A2. List of abbreviations used

\begin{tabular}{|l|l|}
\hline Abbreviation & Meaning \\
\hline A & Amortisation \\
\hline Aa $_{a}$ & Average Total Assets \\
\hline AP & Accounts Payable \\
\hline Atotal & Total Assets \\
\hline CV & Company Value \\
\hline DOE & Daily Operating Expense \\
\hline$D_{\text {outstanding }}$ & Outstanding Debt \\
\hline$D_{\text {sv }}$ & Integral Indicator - Standardized Variable \\
\hline Es & Earnings per Share \\
\hline Lc & Current Liabilities \\
\hline LD & Long-term Debt \\
\hline Liother & Other Liabilities \\
\hline LV & Lease Value \\
\hline MS & Marketable Securities \\
\hline Ps $_{\text {RC }}$ & Share Price \\
\hline
\end{tabular}

